This is an accepted version of the below article which will be published by Elsevier in Industrial Marketing Management.

Downloaded from SOAS Research Online: http://eprints.soas.ac.uk/21996/

What is Dark about the Dark-Side of Business Relationships?

\author{
Ibrahim Abosag \\ SOAS, University of London \\ Email: Ibrahim.abosag@soas.ac.uk
}

\author{
Dorothy A. Yen \\ Brunel University London \\ Email: Dorothy.yen@brunel.ac.uk
}

Bradley R. Barnes

Sheffield Business School

Email: b.r.barnes@shu.ac.uk 


\section{What is Dark about the Dark-Side of Business Relationships?}

Over the last decade or so, the term 'dark-side' in referring to business relationships has been increasingly used in academic discourse. Despite such a growth in the number of studies, relatively little critique has been offered among scholars. The fact that effectively managing the dark side of business relationships has potentially greater influence of contributing to inter-organizational success beyond more focus on the positive side necessitates an urgent critique surrounding 'what is dark about the dark side of business relationships?' Thus, we aim to provide an overview relating to the 'dark side' of business relationships in a quest to generate greater debate on the subject.

\section{Introduction}

Businesses spend significant amounts of time to build and maintain a host of relationships with their key stakeholders. Such efforts usually result in positive impact through increased trust, greater commitment and further relationship cooperation. These in turn often encourage parties to develop reciprocal norms that enhance value creation through continuous learning, interaction, as well as promoting psychological closeness and reciprocity (De Wulf et al., 2001; Palmatier et al., 2009). Thus, it is not surprising to see that much of the business-to-business literature has been devoted to enabling relational parties to invest in activities and strategies aimed at building positive relationships. However, in order to ensure overall success, investing in positive elements of relationships alone is not enough, as business partners must protect against detrimental perceptions, actions and behaviours (e.g. Gaski, 1984; John, 1984; Moorman, Zaltman \& 
Deshpande, 1992; Blois, 1997; Grayson and Ambler, 1999; Hibbard et al. 2001; Barnes, 2005; Anderson \& Jap, 2005; Villena, Revilla \& Choi, 2011; Fang et al., 2011).

In fact, research from behavioral science suggests that reducing the negative impacts of the dark-side within the relationship has greater influence on the success of business relationships than investing purely on the development of positive relationships (Baumeister et al., 2001). Such the prominent role of the negative elements of business relationships has encouraged researchers over the past two decades to focus on this area. While most have only partially examined such negative elements, a few studies have been purely devoted to this subject (e.g. Gaski, 1984; John, 1984; Mooi \& Frambach, 2012; Mysen et al., 2011).

Increased attention on the dark-side of relationships has helped to provide a greater understanding of the nature of business relations, which often require careful management. Knowing how negative relational elements impact on relationships is likely to prove useful for both academic and practitioners. With this aim, this introductory overview provides a critical discussion of 'dark-side' relationships and attempts to answer the question of what is dark about the dark-side? The introduction proceeds by a discussion of tolerable, irritating and intolerable dark-side relationships and some suggestions for future research are provided.

\section{What is dark?}

Despite the recent widespread use of the term 'dark-side' in business relationships, very little critique of the literature and this subject has been offered. The notion of a 'dark side' suggests 'problems', 'challenges', 'difficulties', and 'drawbacks' related to structural issues that exist in business relationships, such as size differences, or the imbalance of power; processes within business relationships, including creativity issues, capability development, changes in market dynamics; and outputs, for example performance, competitiveness and satisfaction.

The term 'dark-side' first emerged in the business-to-business literature in the mid to late 1990s and further work has continued around this theme well into the new century 
(Hakansson \& Snehota, 1995; Grayson \& Ambler, 1999; Barnes, 2005; Anderson \& Jap, 2005). Earlier studies did not use this term, but generally referred to a 'negative side' that focused on related constructs (e.g. Gaski, 1984; John, 1984; Moorman, Zaltman \& Deshpande, 1992). Other studies have referred to it as 'relationship unrest' (Good \& Evans, 2001), 'relationship burdens' (Hakansson \& Snehota, 1998), 'relationship stress' (Holmlund-Rytkönen \& Strandvik, 2005), 'the adverse sides' of business relationships (Strandvik \& Holmlund, 2008), 'relational misconduct' (Hawkins et al., 2008; Jensen, 2010), and 'detrimental intentions' (Pressey, Tzokas \& Winklhofer, 2007; Liu et al., 2014). Anderson and Jap (2005) argued that most relationships that appear strong are often vulnerable to forces that are quietly going on beneath the surface. Although the degree of 'darkness' can vary in business relationships, in terms of impact and consequence, the dark-side has a contradictory effect on typically good-functioning relationships (Burt, 1999).

Often business relationships are neither bright nor dark, but rather represent a combination of the two. It has long been recognized in the literature that the dark-side is inspirable from the very meaning of relationships (Hakansson \& Snehota, 1998). According to Hakansson \& Snehota (1995) relationships that are valuable in certain ways may also have some aspects of negativity. Similarly, Grayson \& Ambler (1999) pointed out that relationships can have specific benefits, yet also have their inherent drawbacks. Furthermore, Samaha, Palmatier \& Dant (2011) explain that over time relationships invariably are damaged and understanding this is critical for long-term success. The darkside represents a natural component of business relationships and is unavoidable, but it can be successfully managed and reduced. Such dark-side effects have also been found to exist in medium-term (Barnes, 2005), long-term (Grayson \& Ambler, 1999), and in close business relationships (Noordhoff, Kyriakopoulos, Moorman, Pauwels \& Dellaert, 2011). According to Hakansson \& Snehota (1998) the risk of such dark-side effects can never be ruled out, as they are the systematic consequence in terms of the development of such relationships.

Despite researchers overwhelming recognition of the important of understanding the dark-side in business relationship (e.g. Hakansson \& Snehota, 1995; Grayson \& Ambler, 
1999; Fang, Chang \& Peng, 2011), the degree of darkness can be outlined along a spectrum of increased darkness. Figure 1 shows the increased spectrum of darkness in business relationships, by specifically addressing tolerable dark-side and intolerable darkside. Immediately above the spectrum are the notions that reflect different degrees of darkness. Below the spectrum are reactive behavioral traits to the increased darkness.

Figure 1: The Spectrum of Increased Darkness.

\begin{tabular}{|c|c|c|c|c|c|}
\hline \multirow{2}{*}{\multicolumn{3}{|c|}{ Low Uncertainty }} & \multicolumn{2}{|c|}{ Unfairness } & \multirow[b]{3}{*}{$\begin{array}{l}\text { Relationship } \\
\text { Termination }\end{array}$} \\
\hline & & & \multicolumn{2}{|c|}{ High Uncertainty } & \\
\hline Learning & \begin{tabular}{|l|} 
Expected/routine \\
Conflict \\
\end{tabular} & Tension & Severe Conflict & \begin{tabular}{|l} 
Opportunistic \\
Behavior
\end{tabular} & \\
\hline & Adaptation & $\begin{array}{l}\text { Increased } \\
\text { Distance }\end{array}$ & $\begin{array}{l}\text { Worries of } \\
\text { Misbehavior }\end{array}$ & $\begin{array}{l}\text { Accelerating } \\
\text { Deterioration }\end{array}$ & \\
\hline \multicolumn{3}{|c|}{ Tolerable Dark-Side } & \multicolumn{2}{|c|}{ Intolerable \& irritating dark-side } & \\
\hline
\end{tabular}

\section{The tolerable dark-side}

In our view, business relationships are not inherently good or bad but rather, relationships can produce both simultaneous bright and dark-side effects. Such dark-side effects in their early appearance may be useful if businesses are capable of effective learning. However, failure to learn and adapt within business relationships can allow for early conflict to appear (Ford, 1980). Being tolerable to such dark-side effects may therefore be essential for managers to realize in order for them to acquire realistic relationship expectations (Hakansson \& Snehota, 1995). Awareness of the sources that can contribute to the dark-side can help to play a significant role in dealing with their effects on the relationship. The dark-side can stem from different sources including moderate levels of moral hazards (Wuyts \& Geyskens, 2005), the adverse selection of a partner (Swink \& Zsidisin, 2006), close interpersonal ties (Noordhoff et al., 2011), and imprecise contractual agreements (Dewatripont \& Sekkat, 1991).

However, once the dark-side appears in a relationship, uncertainty immediately emerges too. The negative impact of environmental uncertainty has been well documented in the literature (e.g. Geyskens et al., 1998). Relationship uncertainty can be the outcome of negative interactions, engagement and communications. Uncertainty is 
defined as the extent to which a partner has sufficient information to foresee the consequences of their decisions and enable them to make key decisions with confidence (Achrol \& Stern, 1988). Initial appearance of a dark-side in business relationships leads to low levels of uncertainty. Thus, through the effective sharing of information and flexibility in terms of adaptation, levels of uncertainty can be reduced. Failure to exchange information and an unwillingness to adapt allows uncertainty to increase and prevents businesses from seeing unanticipated changes in circumstances around the relationship (Noordeweir et al., 1990). This can often make it more challenging for predicting partners' demands and behaviours (Kohli, 1989).

The dark-side frequently results in conflicting views around issues relating to the relationship. Conflict is a disagreement between partners (Dwyer et al., 1987), yet it can be resolved as part of on-going business (Anderson \& Narus, 1990). Therefore, although routine and expected conflict can exist in most relationships, it may be useful for helping business partners to correct, modify and change their ways to enhance value (Wang et al., 2008). Conflict may arise from differing goals, expectations, or the clashing of cultural norms (Araujo \& Mouzas, 1997). The effective handling of conflict can lead to increased productivity (Anderson \& Narus, 1990), improved creativity (Bengtsson \& Kock, 2000; Gadde \& Hakansson, 2010), further relationship benefits (Vaaland \& Hakansson, 2003), and greater value creation (Möller \& Törrönen, 2003; Mele, 2011). However, what tends to matter when trying to resolve conflict is the parties' attitudes. While positive attitudes toward conflict enable managers to see its usefulness and long-term benefits for the relationship (Jehn \& Mannix, 2001), negative attitudes increase uncertainty and tension (Tjosvold et al., 2003). Rose \& Shoham (2004) argue that international partners can be particularly prone to such negative conflict. Meanwhile unresolved conflict can disrupt learning and impede on the sharing of information (Chang \& Gotcher, 2010), which in turn increases the emotional distance and tension between relational partners.

The impact of the dark-side will increase in relationships when expected and routine conflicts are not dealt with swiftly or successfully. Tension causes stress and discomfort (Proenca \& de Castro, 2005), provokes unrest (Good \& Evans, 2001), and weakens relationship quality (Dwyer et al., 1987). Dark-side relationships occur when 
tensions emerge (Fang, Chang \& Peng, 2011). Tension singles the end of two important factors in relationships. Firstly, it signals the end of harmonization within relationships that typically involve enhancing trust and future commitment. Secondly, tension can initiate the weakening of previously strong relationships. The danger of tension within relationships is that it can serve as a motive for punishing non-cooperative behavior, adding further costs, wasting opportunities and it has the potential to cause severe and unrepairable conflict. Studies in sociology have demonstrated a link between tension and increased conflict (Jensen, 2010). In studying tension, Fang et al. (2011) argued that it occurs as a result of contradictory goals, resulting in tension imbalance. While this is helpful for learning more and understanding the role of tension in relationships, there is an apparent absence of studies focusing on tension in relationships, especially in terms of its possible effects on dangerous levels of conflict and misbehavior.

\section{Intolerable and irritating dark-side relations}

Dark-side relationships are characterized by negative attitudes to conflict, high tension, severe conflict, and the deterioration of trust, commitment and cooperation. Severe conflict is a clear manifestation of dark-side relationships that are irritating, often costly, and cause increasing worries of opportunism. Within this literature, high levels of conflict can be detrimental, leading to reduced productivity, cooperation and performance (Skarmeas, 2006; Massey \& Dawes, 2007; Finch, Zhang \& Geiger, 2013). It can also serve to destroy any value co-creation (Zhou, Zhuang \& Yip, 2007; Meunier-Fitz Hug, Massey \& Piercy, 2011; Mele, 2011). High levels of conflict often result in unhealthy behavior such as hostility, distortion, distrust and withholding of information to the detriment of the relationship partner (Menon et al. 1996; Grayson and Ambler, 1999; Selnes \& Sallis, 2003; Anderson \& Jap, 2005). According to Yang et al. (2012) severe conflict can have a more negative effect in relationships with high levels of trust than in

relationships with lower levels of trust. Severe levels of conflict reduce loyalty (Plank \& Newell, 2007) and result in less joint decision-making and high uncertainty (Leonidou et $a l ., 2006)$. High levels of conflict can encourage greater opportunism leading to a real 
chance of relationship dissolution (Halinen \& Tahtinen, 2002; Wang et al., 2010; Yang et al., 2012).

Severe conflict in relationships significantly increases such dark-side effects, including worries regarding opportunism and an increasing likelihood of misbehavior. Opportunism is motivated by the desire to independently exploit a relationship for selfinterest or gain and tends to lead to short-term exploitation (Das \& Rahman, 2010), particularly dark behavior so much as it violates existing agreements (Liu et al., 2014). Weak levels of trust and commitment increase the threat that one of the relational partners will engage in opportunistic behavior (Caniëls et al., 2010), which in turn can encourage retaliation and the use of power (Maloni \& Benton, 2000).

Many studies have found that opportunism is a true dark force that negatively influences relationships (e.g. Morgan \& Hunt, 1994; Joshi \& Stump, 1999; Nunlee, 2005; Crosno \& Dahlstrom, 2008; Yang \& Wang, 2013). However, Hawkins et al. (2008, 2013) argued that opportunism in relationships should be both expected and accepted. There may also be a need to differentiate between weak and strong forms of opportunism (Luo, 2006), as well as combining moral intensity and ethics. Strong forms of opportunism violate contractual norms and weak forms violate relational norms (Luo, 2006). Recently, Jap et al. (2013) questioned whether opportunism causes relationship instability. While these recent claims require further empirical examination and greater context specification, overall opportunism is motivated by and leads to greater use of power (Ireland \& Webb, 2007). Power not only leads to opportunism, but it can also destroy strong collaborative relationships (Maloni \& Benton, 2000; Zhuang, Xi, \& Tsang, 2010).

Although severe conflict and opportunism can truly drag relationships to the darkside which may seriously lead to their termination, another significant negative effect that can occur at this stage, is perceived unfairness. Samaha et al. (2011, p. 99) claimed that "perceived unfairness acts as 'relationship poison' by directly damaging channel relationships, aggravating the negative effects of both conflict and opportunism". Perceived unfairness motivates actors to take revenge and punishing actions. Fehr \& Gachter (2000) suggest that individuals may go out of their way to revenge against unfair behavior. Crosno \& Dahlstrom (2008) argued that the effects of conflict and opportunism 
are contingent on the levels of unfairness, and these were all discussed by Samaha et al. (2011) as potential 'relationship-destroying factors'.

The combined effects from these factors can therefore damage and lead to termination of previously strong and collaborative relationships. While the literature provides us with a great deal of understanding on how to manage conflict, research on how to suppress and respond to opportunistic behavior is scant. Similarly, there is an apparent lack of studies on how to manage perceptions of unfairness and deal with emotionally charged partners who seek to punish unfair partners.

\section{Contributions to this Special Issue}

The special issue consists of nine empirical papers from diverse business-to-business areas. Each paper provides fresh insights and adds new understandings to this area on dark-side relationships. With the aim to answer whether the dark personality trait, desire for control, manifests itself through control mechanisms in a manner detrimental to alliance performance; Musarra, Robson \& Katsikeas (2016 - this issue) demonstrate that a focal firm's desire for control is positively associated with process monitoring as well as output monitoring.

Building on theoretical perspectives of organizational capability, organizational networking and social capital theories, Chung, Wang, Huang \& Yang (2016 - this issue) investigate the boundary conditions of personalized business-to-business relationships (managerial ties) on business performance. The findings demonstrate the dark side of political and business ties. Meanwhile Heirati, O'Cass, Schoefer \& Siahtiri (2016 - this issue) examined the conditions under which bright-side benefits of professional service firms' interfirm collaboration turn into dark-side drawbacks. The researchers found that increasing levels of competitive intensity and environmental turbulence encountered by a professional service firm can diminish the capacity of customer and supplier collaboration to drive service performance.

In exploring the dark-side of institutionalized creativity within the context of client-agency relationships, Vafeas \& Hughes (2016 - this issue) identify factors that 
might suppress the dark-side of such relationships. Using a grounded theory approach to investigate the dark-side within a logistics outsourcing relationship, Schmitz, Schweiger \& Daft (2016 - this issue) identify four interrelated mechanisms (convincing, tying, complementing and lock-in) that explain dependence and lock-in from a buyer's perspective. In examining dark network tension and specifically the nature of opportunism in price-fixing cartels, Pressey \& Vanharanta (2016 - this issue) found that network tension is made significantly worse by the illicit nature of cartels and their opportunistic behaviour.

Meanwhile, in studying the dark side of using reseller networks for providing after-sales service, Gupta, Väätänen \& Khaneja (2016 - this issue) found that the dark side of network interdependence negatively affects the shared brand-reseller goal of value co-creation. Moreover, in further researching the dark side effects of value co-creation in business-to-business service networks, Chowdhury, Gruber \& Zolkiewski (2016 - this issue) discovered that there are negative aspects associated with value co-creation in advertising service networks. The authors identified role conflict and ambiguity, opportunism and power as key attributes that influence on the dark side in such value cocreation activities.

Finally Tangpong, Li \& Hung (2016 - this issue) investigated the impact of reciprocity norms on ethical compromise. Their study revealed that environmental uncertainty, exchange partner's retaliatory power status, trust and perceived future gain opportunity in relationships serve as potential mediating mechanisms on the reciprocity norm-ethical compromise relationship. Overall, we hope that you will enjoy reading this Special Issue on the dark-side of business relationships and such studies will encourage further research in this field for years to come. 


\section{References:}

Achrol, R. \& Stern, L. (1988). "Environmental determinants of decision-making uncertainty in marketing channels", Journal of Marketing Research, Vol. 25, No. 1, pp. 36-50.

Anderson, E. \& Jap, S. D. (2005).“The dark side of close relationships," MIT Sloan Management Review, 46(3), 75-82.

Anderson, J. \& Narus J. A. (1990). A model of distributor firm and manufacturer firm working partnerships. Journal of Marketing, 54(1), 42-58.

Barnes, B. R. (2005). Is the seven-year hitch premature in industrial markets. European Journal of Marketing, 39(5/6), 560-581.

Baumeister, R., Bratslavsky, E., Finkenauer, C. \& Voks, K. (2001). Bad is stronger than good. Review of General Psychology, 5, 323-370.

Bengtsson, M. \& Kock, S. (2000). Coopetition in business networks: to cooperate and compete simultaneously. Industrial Marketing Management, 29 (5) 411-426.

Blois, K. (2010). The legitimacy of power in business-to-business relationships. Marketing Theory, 10, 161-172.

Caniëls, M., Gelderman, C. \& Ulijn, J. (2010). Buyer-supplier relationship development: an empirical study among Dutch purchasing professionals. Journal of Enterprising Culture, 18(2), 107-37.

Chang, K. \& Gotcher, D. (2007). Safeguarding investments and creation of transaction value in asymmetric international subcontracting relationships: the role of relationship learning and relational capital. Journal of World Business, 42(4), 477-88. 
Crosno, J. L. \& Dahlstrom, R. (2008). A meta-analytic review of opportunism in exchange relationships. Journal of the Academy of Marketing Science, 36 (2), 191-201.

De Wulf, K., Odekerken-Schroder, G. \& Iacobucci, D. (2001. Investments in consumer relationships: a cross-country and cross-industry exploration. Journal of Marketing, 65, 33-50.

Dewatripont, M. \& Sekkat, K. (1991). Producer opportunism in retailing contracts. The Journal of Industrial Economics, 39(5), 595-620.

Dwyer, F. Schurr, P. \& Oh, S. (1987). Developing buyer-seller relationship. Journal of Marketing, 51(2), 11-27.

Fang, S., Chang, Y., \& Peng, Y. (2011). Dark side of relationships: A tensions-based view. Industrial Marketing Management, 40(5), 774-784.

Fehr, E. \& Gächter,S. (2000). Fairness and retaliation: the economics of reciprocity, Journal of Economic Perspectives, 14(3), 159-81.

Finch, J., Zhang, S. \& Geiger, S. (2013). Managing in conflict: how actors distribute conflict in an industrial network. Industrial Marketing Management, 42(7)10631073.

Ford, D. (1980). The Development of buyer-seller relationships in industrial markets. European Journal of Marketing, 14(5/6), 339-353.

Gadde, L-E. \& Håkansson, H., (2010). Supply Network Strategies. Chichester: John Wiley.

Gaski, J. (1984). The theory of power and conflict in channels of distribution. Journal of Marketing, 48(3), 9-29.

Geyskens, I., Steenkamp, J. \& Kumar, N. (1998). Generalizations about trust in marketing channel relationships ssing meta-analysis. International Journal of Research in Marketing, 15, 223-248.

Good, D. J. \& Evans, K. R. (2001). Relationship unrest-a strategic perspective for business-to-business marketers. European Journal of Marketing, 35(5/6), 549565.

Grayson, K. \& Ambler, T. (1999). The Dark side of long-term telationships in marketing services.Journal of Marketing Research, 36(1), 132-141. 
Gu, F. F., Hung, K., \& Tse, D. K. (2008). When does Guanxi matter? Issues of capitalization and its dark sides. Journal of Marketing, 72(4), 12-28.

Hakansson, H. \& Snehota, I. (1995). The burden of relationships or who's next. IMP $11^{\text {th }}$ International Conference, Manchester (UK), September 7th- $9^{\text {th }}$, pp. 522-536.

Hakansson, H., \& Snehota, I. (1998). The burden of relationships or who's next?, in Naude P, Turnbull PW, (Eds.), Network Dynamics in International Marketing, Pergamon, Oxford, 16-25.

Halinen, A. \& Tahtinen, J. (2002). A process theory of relationship ending. International Journal of Service Industry Management, 13(2), 163-180.

Hawkins, T., Pohlen, T. \& Prybutok, V. R. (2013). Buyer opportunism in business-tobusiness exchange. Industrial Marketing Management, 42(8), 1266-1278.

Hawkins, T. G., Wittman, C. M., \& Beyerlein, M. M. (2008). Antecedents and consequences of opportunism in buyer-supplier relations: Research synthesis and new frontiers. Industrial Marketing Management, 37(8), 895-909.

Hibbard, J., Kumar, N. \& Stern, L. (2001). Examining the impact of destructive acts in marketing channel relationships. Journal of Marketing Research, 38, 20-65.

Holmlund-Rytkönen, M. \& Strandvik, T. (2005). Stress in business relationships. Journal of Business \& Industrial Marketing, 20(1), 12-22.

Ireland, R. \& Webb, J. W. (2007). A multi-theoretic perspective on trust and power in strategic supply chains. Journal of Operations Management, 25(2), 482-497.

Jehn, K. \& Mannix, E. (2001).The dynamic nature of conflict: a longitudinal study of intragroup conflict and group performance. Academy of Management Journal, 44(2), 238-251.

Jensen, (2010). Punishment and spite, the dark side of cooperation. Philosophical Transitions of the Royal Society, 365, 2635-2650.

John, G. (1984). An empirical investigation of some antecedents of opportunism in a marketing channel. Journal of Marketing Research, 21(3), 278-289.

Joshi, A. \& Stump, R. (1999). Determinants of commitment and opportunism: integrating and extending insights from transaction cost analysis and relational exchange theory. Canadian Journal of Administrative Sciences, 16(4), 334-352. 
Kohli, A. (1988). Determinants of influence in organizational buying: a contingency approach, Journal of Marketing, 53(3), 50-65.

Leonidou, L., Barnes, B. \& Talias, M. (2006). Exporter-importer relationship quality: the inhibiting role of uncertainty, distance, and conflict. Industrial Marketing Management, 35(5), 576-588.

Liu, Y., Liu, T., \& Li, Y. (2014). How to inhibit a partner's strong and weak forms of opportunism: Impacts of network embeddedness and bilateral TSIs. Industrial Marketing Management, 43(2), 280-292.

Maloni, M. \& Benton, W. (2000). Power influences in the supply chain. Journal of Business Logistics, 21(1), 49-73.

Massey, G. \& Dawes, P. (2007). The antecedents and consequence of functional and dysfunctional conflict between marketing managers and sales managers. Industrial Marketing Management, 36(8), 1118-1128.

Mele, C. (2011). Conflict and value co-creation in project networks. Industrial Marketing Management, 40(8), 1377-1385.

Menon, A., Bharadwaj, S. \& Howell, R. (1996). The quality and effectiveness of marketing strategy: Effects of functional and dysfunctional conflict in intraorganizational relationships. Journal of the Academy of Marketing Science, 24(4), 299-313.

Meunier-Fitz Hug, K., Massey, G. \& Piercy, N. (2011).The impact of aligned rewards and senior manager attitudes on conflict and collaboration between sales and marketing. Industrial Marketing Management, 40(7), 1161-1171.

Möller, Kristian \& Pekka Törrönen (2003). Business suppliers’ value creation potential. A capability-based analysis. Industrial Marketing Management, 32 (2), 109-118.

Mooi, E. A., \& Frambach, R. T. (2012). Encouraging innovation in business relationships-A research note. Journal of Business Research, 65(7), 1025-1030.

Moorman, C., Zaltman, G. \& Deshpande, R. (1992). Relationships between providers and users of market research: the dynamics of trust within and between organizations. Journal of Marketing Research, 29(3), 314-328.

Morgan, R. \& Hunt, S. D. (1994). The commitment-trust theory of relationship marketing. Journal of Marketing, 58(3), 20-38. 
Mysen, T., Svensson, G., \& Payan, J. M. (2011). The key role of opportunism in business relationships. Marketing Intelligence \& Planning, 29(4), 436-449.

Noordeweir, T., John, G. \& Nevin, J. (1990). Performance outcomes of purchasing arrangements in marketing channels: a theoretical perspective. Journal of Marketing, 54(October), 80-93.

Noordhoff, C. S., Kyriakopoulos, K., Moorman, C., Pauwels, P., \& Dellaert, B. G. (2011). The bright side and dark side of embedded ties in business-to-business innovation. Journal of Marketing, 75(5), 34-52.

Nunlee, M. P. (2005). The control of intra-channel opportunism through the use of interchannel communication. Industrial Marketing Management, 34(5), 515-525.

Palmatier, R., Jarvis, C., Bechkoff, J. \& Kardes, F. (2009). The role of customer gratitude in relationship marketing. Journal of Marketing, 73(5), 1-18.

Plank, R. \& Newell, S. (2007). The effect of social conflict on relationship loyalty in business markets. Industrial Marketing Management, 36(1), 59-67.

Pressey, A., Tzokas, N., \& Winklhofer, H. (2007). Strategic purchasing and the evaluation of "problem" key supply relationships: what do key suppliers need to know? Journal of Business \& Industrial Marketing, 22(5), 282-294.

Proença, J. \& de Castro, L. (2005). 'Stress' in business relationships: a study on corporate bank services. International Journal of Bank Marketing, 23(7), 527-541.

Rose \& Shoham (2004). Interorganizational task and emotional conflict with international channels of distribution. Journal of Business Research, 57(9), 942950.

Saavedra, R., Earley, P. C.\& Van Dyne, L. (1993). Complex interdependence in taskperforming groups. Journal of Applied Psychology, 78, 61-72.

Samaha, S. A., Palmatier, R. \& Dant R. P. (2011). Poisoning relationships: Perceived unfairness in channels of distribution. Journal of Marketing, 75(May), 99-117.

Selnes, F. \& Sallis, J. (2003). Promoting relationship learning. Journal of Marketing, 67(3), 80-95.

Skarmeas, D. (2006). The role of functional conflict in international buyer-seller relationships: Implications for industrial exporters. Industrial Marketing Management, 35(5), 567-575. 
Strandvik, T., \& Holmlund, M. (2008). How to diagnose business-to-business relationships by mapping negative incidents. Journal of Marketing Management, 24(3-4), 361-381.

Swink, M. \& Zsidisin, G. (2006). On the benefits and risks of focused commitment to suppliers. International Journal of Production Research, 44(20), 4223-4240.

Tjosvold, D., Hui, C., Ding, D. \& Hu, J. (2003). Conflict values and team relationships: conflict's contribution to team effectiveness and citizenship in China. Journal of Organizational Behavior. 24(1), 69-88.

Vaaland, T. \& Håkansson, H. (2003). Exploring interorganizational conflict in complex projects. Industrial Marketing Management, 32 (2), 127-138.

Villena, V. and Revilla, E. \& Choi, T. (2011). The dark side of buyer-supplier relationships: a social capital perspective. Journal of Operations Management, 29(6), 561-576.

Wang, Q., Kayande, U., \& Jap, S. (2010). The seeds of dissolution: Discrepancy and incoherence in buyer-supplier exchange. Marketing Science, 29(6), 1109-1124.

Wuyts, S. \& Geyskens, I. (2005). The formation of buyer-supplier relationships: detailed contract drafting and close partner selection. Journal of Marketing, 69(4), 103117.

Yang, D., Sivadas, E., Kang, B., \& Oh, S. (2012). Dissolution intention in channel relationships: An examination of contributing factors. Industrial Marketing Management, 41(7), 1106-1113.

Yang, X., \& Wang, Z. (2013). Inter-firm opportunism: A meta-analytic review and assessment of its antecedents and effect on performance. The Journal of Business and Industrial Marketing, 28(2), 137-146.

Zhou, N., Zhuang, G. and Yip, L. (2007). Perceptual difference of dependence and its impact on conflict in marketing channels in China: An empirical study with twosided data. Industrial Marketing Management, 36(3), 309-321.

Zhuang, G., Xi, Y., \& Tsang, A. (2010). Power, conflict, and cooperation: The impact of guanxi in Chinese marketing channels. Industrial Marketing Management, 39(1), 137-149. 